\title{
Miscanthus sacchariflorus В СИБИРИ: ПАРАМЕТРЫ ПРОДУКЦИОННОГО ПРОЦЕССА, ДИНАМИКА БИОФИЛЬНЫХ ЭЛЕМЕНТОВ*
}

\author{
С.Ю. КАПУСТЯНЧИК ${ }^{1}{ }^{\circledR}$, А.А. ДАНИЛОВА², И.Е. ЛИХЕНКО 1
}

В мире энергетические культуры возделывают для замены ископаемых ресурсов и сокращения выбросов парниковых газов. Одного из перспективных представителей таких культур мискантус (Miscanthus spp.) широко культивируют преимущественно в странах с гидротермическими условиями, оптимальными для этого растения. В России проблема выращивания мискантуса в целях получения биомассы остается слабо изученной. В настоящей работе мы оценили возможность культивирования мискантуса для получения биомассы в континентальных условиях Сибири. Исследования провели на территории научно-экспериментальной базы СибНИИРС - филиал ИЦиГ СО РАН (Новосибирская область, Центральная лесостепь Новосибирского Приобья, 54 53 ' 13,5"N, 82 59'36,7"Е). Параметры продукционного процесса изучили у Miscanthus sacchariflorus сорта Сорановский (Государственный реестр селекционных достижений, патент № 6931 от 06.06.2013) в условиях агро-серой почвы. В период формирования многолетних посадок (1-4 года) мискантуса запас надземной биомассы достиг $12 \pm 1$, подземной $-17 \pm 1$ т/га. Эти показатели близки к средним характерным для этого вида в мире. Общий вынос NPK всей надземной биомассой (стебли + листья) составил соответственно 51, 6 и 49 кг/га, вынос с урожаем только стеблей 23, 3 и 26 кг/га. При этом запас NPK в подземной биомассе составил соответственно 130, 10 и 126 кг/га. Следовательно, причин для истощения в почве запасов биофильных элементов при произрастании мискантуса в условиях опыта в течение 4 лет не обнаружено. Установлено наличие объективных предпосылок для закрепления углерода атмосферы во фракциях органического вещества агро-серой почвы: за первые 2 года вегетации мискантуса в мобильных фракциях органического вещества накопилось не менее 300 кг/га углерода; повышение отношения $\mathrm{C} / \mathrm{N}$ в подземной биомассе мискантуса до 74 (в исходной почве - 20) сопровождалось существенным снижением скорости минерализации вновь поступающих растительных остатков. Параметры продукционного процесса M. sacchariflorus сорта Сорановский в условиях агро-серой почвы в Центральной лесостепи Приобья соответствовали присущим виду M. sacchariflorus, культивируемому в других регионах мира на разных типах почв. Сделан вывод, что выращивание указанной культуры в целях получения биомассы в условиях Сибири может быть обоснованным с экологической, агротехнической и экономической точек зрения.

Ключевые слова: энергетические растения, Miscanthus sacchariflorus, сорт Сорановский, надземная биомасса, подземная биомасса, вынос элементов питания, накопление углерода в почве.

Производство возобновляемых источников топлива и сырья становится одним из условий выживания человечества. Выращивание биоэнергетических растений признается одним из важнейших способов решения этой проблемы. Среди таких растений одними из перспективных в мире считают представителей рода Miscanthus spp. семейства Злаки (Poaceae). Это связано как с ценными химическими свойствами биомассы, так и с характерными для этого растения высокими темпами роста и колоссальной биологической продуктивностью, в том числе в условиях умеренного климата. Биомассу мискантуса используют в качестве возобновляемого источника топлива, для производства лигниноцеллюлозной биомассы, строительных и композитных материалов (заменителей дерева и пластмасс) $(1,2)$. Из биомассы также получают хлорофилл и производят бумагу (3).

К роду Miscanthus относят более 20 видов, распространенных от тропической и Южной Африки до Восточной и Юго-Восточной Азии. В России на Дальнем Востоке встречается 3 вида: мискантус сахароцветковый (Miscanthus sacchariflorus), мискантус краснеющий (M. purpurascens) и мискантус китайский (M. sinensis) (4).

* Работа поддержана бюджетным проектом ИЦиГ СО РАН № 0324-2019-0039-С-01 и государственным заданием ФГБУН СФНЦА РАН (проект № 0778-2018-0002). 
В мире (в Норвегии, Германии, Дании, Великобритании, США, Канаде, других регионах) накоплен достаточно большой опыт выращивания энергетических культур, в том числе нескольких видов рода Miscanthus. В настоящее время основные площади посадок этих растений расположены преимущественно в странах со среднегодовой положительной температурой воздуха выше 5-10 ${ }^{\circ} \mathrm{C}$ и суммой осадков за год не менее 600 мм (Северная Америка, Европа). Наиболее широко культивируют вид M. giganteus, который выделяется особо высокой продуктивностью в названных выше климатических зонах. Низкая морозоустойчивость этого вида (5-7) снижает его перспективность для выращивания в условиях Российской Федерации.

В Сибири мискантус достаточно известен в качестве декоративного растения. Проблема выращивания культуры в целях получения биомассы в условиях Сибири остается практически не изученной. Возникла необходимость селекции местных сортов мискантуса, способных поддерживать высокую продуктивность при лимитирующих факторах континентального климата. На основе коллекции диких видов мискантуса, отобранных на Дальнем Востоке России, был выведен сорт Сорановский (8), который методами фенотипирования и анализа ДНК отнесен к виду M. sacchariflorus (9). Растения этого вида длиннокорневищные, имеют высоту до 2,0-2,5 м, стебель прямой, жесткий, с опушенной вокруг листовой оболочкой. Листья узкие, ланцетно-линейной формы, длиной до 60 см. Абаксиальная поверхность листовой пластины голая неопушенная, адаксиальная - опушенная с беловатой заметной серединой и цельной формой края. Соцветие в форме веерообразной метелки бледно-фиолетового цвета в начале цветения и бело-серого - при его завершении, длиной до 25 см. Ось соцветия короткая, с длинными кистями.

M. sacchariflorus сорта Сорановский в сравнении с видом M. giganteus характеризуется более высокой морозо- и засухоустойчивостью, что позволяет признать его перспективность для культивирования в условиях Сибири (10). Отличительная особенность сорта - образование очень длинных корневищ, быстро колонизирующих свободное пространство. В результате за короткий период формируется сплошная ровная плантация, успешно конкурирующая с сорной растительностью. Как известно, плантация M. giganteus из-за коротких корневищ медленно колонизирует пространство и представляет собой разросшиеся кочки с пустыми участками, занятыми сорной растительностью (10).

Широкомасштабный эксперимент, имевший целью сравнение продуктивности 15 генотипов M. giganteus, M. sinensis и M. sacchariflorus в разных климатических зонах (Великобритания, Германия, Нидерланды, Украина, Турция, Россия - Московская область) показал, что у M. sacchariflorus в сравнении с M. giganteus и M. sinensis зависимость величины биомассы от климатических условий более выражена (11). В связи с этим обоснование возможности культивирования M. sacchariflorus в континентальных условиях требует специальных исследований.

Кроме того, для регулирования продукционного процесса мискантуса, в частности для ответа на вопрос о дозах и видах удобрений, необходимы данные по круговороту биофильных элементов в системе почва-растение. Как известно, относительно низкое отчуждение биофильных элементов с урожаем мискантуса связано с тем, что при высыхании биомассы значительная часть элементов возвращается в подземную часть растений (реутилизация). Как отмечается (12-14), величина реутилизации зависит от климатических условий, вида мискантуса, срока уборки урожая.

Значение энергетических растений не ограничивается продукцией 
возобновляемого источника топлива и сырья. В последние годы интерес к этим культурам, особенно к мискантусу, возрастает в связи с проблемой связывания парникового газа $\mathrm{CO}_{2}$. Предполагается, что колоссальная продуктивность биомассы мискантуса будет способствовать закреплению атмосферного $\mathrm{CO}_{2}$ в устойчивых фракциях почвенного органического вещества (ПОВ) (15-19).

В представленной работе мы впервые показали, что новую для России культуру Miscanthus sacchariflorus сорта Сорановский можно выращивать в условиях засушливого и холодного климата Западной Сибири. Мискантус при средней урожайности $10 \pm 1,5$ т/га абсолютно сухого вещества за четыре первых года формирования плантации не истощал почву элементами минерального питания растений, способствовал закреплению углерода атмосферы во фракциях почвенного органического вещества $(1 \pm 0,15$ т С/га в год - в мортмассе, $150 \pm 30$ кг С/га в год - в подвижных фракциях).

Цель исследования заключалась в оценке возможности выращивания M. sacchariflorus сорта Сорановский в континентальных условиях Сибири на основании анализа продуктивности растений, динамики углерода в агроэкосистеме и определения необходимости в минеральных удобрениях.

Методика. Эксперименты выполняли в условиях Центральной ле-

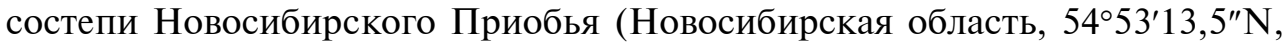
82॰59'36,7"Е). Плантацию мискантуса площадью 0,3 га заложили весной 2015 года на научно-экспериментальной базе СибНИИРС - филиал ИЦиГ СО PАН. В качестве посадочного материала использовали корневища $M$. sacchariflorus сорта Сорановский (оригинатор - Институт цитологии и генетики СО РАН) (9). Наблюдения продолжались в течение 2015-2018 годов.

По данным «АМС Огурцово», в вегетационные периоды в 2015, 2017 и 2018 годах сумма осадков составила соответственно 322, 316 и 297 мм, сумма температур выше $0{ }^{\circ} \mathrm{C}-2396,2340$ и $2199{ }^{\circ} \mathrm{C}$, в 2016 году - 231 мм и $2478{ }^{\circ} \mathrm{C}$ при среднемноголетних значениях 263 мм и $2248{ }^{\circ} \mathrm{C}$. Следовательно, 2015, 2017 и 2018 годы характеризовались как умеренно влажные, а 2016 год был относительно засушливым; во все годы гидротермический коэффициент был одинаковым $($ ГТК $=1)$.

Перед закладкой плантации мискантуса провели почвенно-агрохимическое обследование опытного участка. Почва агросерая типичная. Мощность гумусового горизонта составляла 30-35 см, содержание Сорг. $-1,57-$ $1,76 \%$ (по Тюрину), $\mathrm{N}_{\text {общ. }}-0,13 \%$ (по Кьельдалю), $\mathrm{P}_{2} \mathrm{O}_{5}-30-40$ мг/100 г (по Чирикову), $\mathrm{K}_{2} \mathrm{O}$ в вытяжке - 10-13 мг/100 г (по Чирикову), гидролитическая кислотность - 0,5-1,5 мг-экв/100 г почвы (по Каппену в модификации ЦИНАО), содержание обменных Са и $\mathrm{Mg}$ - около 70 \% емкости катионного обмена (ЕКО). Гранулометрический состав среднесуглинистый.

Для изучения накопления биомассы растений использовали площадки $50 \times 50$ см. Надземную биомассу растений отбирали в 4-кратной повторности ежегодно в течение вегетационного периода по фазам развития мискантуса. Учет биомассы проводили раздельно по органам растений стебли, листья, соцветия (метелки). Подземную биомассу учитывали методом монолитов (высота $25 \mathrm{~cm}$, площадь сечения $10 \times 10 \mathrm{~cm}^{2}$ ) ежегодно в 5кратной повторности при наступлении фазы отмирания надземной биомассы. Мортмассу и корневища отделяли декантацией почвы водой на сите с диаметром ячеек 0,25 мм. Биомассу высушивали до абсолютно сухого состояния. Содержание NPK в надземной биомассе растений определяли ежегодно в фазы всходов, цветения и отмирания. После высушивания биомассы до абсолютно сухого состояния проводили ее мокрое озоление по методу Гинзбург, содержание общего азота определяли по 
Кьельдалю, фосфора - по Труогу, калия - фотометрически (атомно-абсорбционный спектрометр с пламенной атомизацией ААС Квант 2А МТ, ООО «КОРТЭК», Россия) (20). Аналитическая повторность 3-кратная.

На основе фактического содержания элементов в биомассе и общей величины последней рассчитывали вынос азота, фосфора и калия в срок максимального развития надземной биомассы к концу августа-началу сентября (фаза цветение) и при ее высыхании к концу сентября-началу октября. По разности между этими величинами судили о количестве элементов, возвращенных в почву с сухими растительными остатками.

Для определения содержания NPK и органического углерода в подземной биомассе на площадках $50 \times 50$ см корневища отбирали в 5-кратной биологической повторности и каждый образец анализировали в 2-кратной повторности. Содержание NPK в корневищах измеряли осенью 2016 года. Процедура анализа была такой же, как при определении NPK в надземной биомассе. Запас элементов в биомассе и их вынос с урожаем рассчитывали на основе учета величины биомассы и накопления в ней соответствующего элемента. Содержание органического углерода (Cорг.) и общего азота ( $\mathrm{N}_{\text {общ.) }}$ в подземной биомассе определяли на элементном HCNS-анализаторе Vario EL III («Elementar Analysensysteme GmbH», Германия) согласно прилагаемой инструкции производителя.

Отбор почвенных проб для оценки содержания NPK в слоях 0-20 и 20-40 см проводили в 3-кратной повторности на площадках 50×50 см ежегодно в начале (фаза всходов) и в конце (фаза отмирания) вегетации мискантуса. Аналитическая повторность 3-кратная. Агрохимический анализ почвы выполняли по стандартным методикам: фосфор определяли в двух вытяжках по Чирикову и по Карпинскому-Замятиной (ГОСТ 26204-91, М., 1992; ДСТУ 4727:2007, http://www.chemicalnow.ru/chemie-6387.html), азот нитратов - ионометрически (ГОСТ 26951-86, М., 1986), калий - в вытяжке Масловой (ААС Квант 2А МТ, ООО «КОРТЭК», Россия) (ГОСТ 26210-91, М., 1992), содержание органического углерода (Сорг.) - по Тюрину (21).

Показатели, характеризующие метаболизм углерода в почве, оценивали абсорбционным методом по продукции С-CO 2 в лабораторных условиях (22). В пластиковые сосуды объемом 1 л с герметичной крышкой помещали навеску почвы (200 г воздушно-сухой массы). Инкубацию проводили при $25{ }^{\circ} \mathrm{C}$ и влажности $60 \%$ от ППВ. Выделяемый $\mathrm{CO}_{2}$ улавливали 0,1 н. $\mathrm{NaOH}$. Остаток щелочи определяли титрованием при помощи 916 TiTouch («Metrohm AG», Швейцария).

Для определения количества углерода в мобильной фракции ПОВ (лабораторный опыт 1) после первых 2 лет вегетации мы несколько упростили известную методику (23). В опыте задействовали образцы почвы изпод мискантуса и из-под чистого пара. Количество углерода в последней принимали за исходное, так как на этой почве была заложена плантация мискантуса. Повторность опыта 3-кратная. Инкубацию проводили до исчезновения достоверных различий в скорости дыхания почвы между вариантами опыта, что, как считали, указывало на полное разложение запаса подвижного ПОВ, накопленного в почве под мискантусом. Далее по разнице суммарного выделения $\mathrm{C}-\mathrm{CO}_{2}$ из почвы из-под мискантуса и чистого пара рассчитали величину подвижного ПОВ.

Для изучения направленности процессов метаболизма углерода в почве под мискантусом (лабораторный опыт 2) к почвенным образцам (изпод пара и мискантуса) добавляли измельченную солому пшеницы в дозе из расчета 600 мг С/кг почвы. Отклик дыхательной активности почвы оценивали как повышение продукции С-CO 2 в варианте с внесением соломы 
пшеницы (\%) относительно контроля (почвенные образцы, в которые солому не вносили). Повторность опыта 3-кратная.

Статистическую обработку экспериментальных данных проводили в программе MS Excel. Результаты представлены в виде средних $(M)$ со стандартными ошибками средних $( \pm \mathrm{SEM})$ или доверительными интервалами при уровне значимости $\mathrm{p}=0,05\left(t_{0,05} \times \mathrm{SEM}\right)$. О достоверности различий судили по результатам расчета парного $t$-критерия Стьюдента. При фактическом значении критерия ниже принятого в опыте уровня $(0,05)$ различия между вариантами считали достоверными.

Результаты. В результате исследований необходимо было ответить на следующие вопросы: как соотносится продуктивность M. sacchariflorus сорта Сорановский с параметрами развития этого и других видов мискантуса в различных регионах мира; истощается ли почва по основным биофильным элементами при выращивании мискантуса и есть ли необходимость внесения удобрений; какова направленность динамики углерода в агроэкосистеме M. sacchariflorus сорта Сорановский в первые годы формирования посадок.

Фазы развития мискантуса, в которые выполняли учет биомассы растений, представлены в таблице 1.

1. Даты наступления фенологических фаз у растений мискантуса (Miscanthus sacchariflorus) сорта Сорановский по годам наблюдений (Новосибирская обл., $\left.54^{\circ} 53^{\prime} 13,5^{\prime \prime} \mathrm{N}, 82^{\circ} 59^{\prime} 36,7^{\prime \prime} \mathrm{E}\right)$

\begin{tabular}{|c|c|c|c|c|}
\hline Фаза развития & 2015 год & 2016 год & 2017 год & 2018 год \\
\hline Посадка & 14.05 .2015 & - & - & - \\
\hline Всходы & 8.06 .2015 & 24.05 .2016 & 24.05 .2017 & 29.05 .2018 \\
\hline Рост междоузлий & 21.06 .2015 & 02.06 .2016 & 6.06 .2017 & 7.06.2018 \\
\hline Кущение подземное за счет корневищ & 14.07.2015 & - & - & - \\
\hline Выход в трубку & 25.08 .2015 & 14.07.2016 & 15.07.2017 & 17.07.2018 \\
\hline Цветение & 18.09.2015 & 23.08.2016 & 31.08 .2017 & 4.09 .2018 \\
\hline Отмирание & 14.10 .2015 & 30.09 .2016 & 6.10 .2017 & 4.10.2018 \\
\hline $\begin{array}{l}\text { Продолжительность вегетационного } \\
\text { периода, сут }\end{array}$ & 129 & 130 & 136 & 129 \\
\hline
\end{tabular}

Динамика накопления надземной и подземной биомассы мискантуса в годы исследований представлена в таблице 2.

2. Динамика биомассы (абсолютно сухое вещество, т/га) у растений мискантуса (Miscanthus sacchariflorus) сорта Сорановский в период формирования плантации ( $n=12, M \pm \mathrm{SEM}$; Новосибирская обл., $\left.54^{\circ} 53^{\prime} 13,5^{\prime \prime} \mathrm{N}, 82^{\circ} 59^{\prime} 36,7^{\prime \prime} \mathrm{E}\right)$

\begin{tabular}{|c|c|c|c|c|c|c|c|c|c|}
\hline \multirow{3}{*}{$\begin{array}{l}\text { Год } \\
\text { (возраст } \\
\text { посадок) }\end{array}$} & \multicolumn{8}{|c|}{ Надземная } & \multirow{3}{*}{ Подземная } \\
\hline & \multirow{2}{*}{$\begin{array}{l}\text { всходы } \\
\text { листья и } \\
\text { стебель }\end{array}$} & \multicolumn{3}{|c|}{ цветение } & \multicolumn{4}{|c|}{ высыхание } & \\
\hline & & листья & стебель & метелка & листья & стебель & метелка & суммарно & \\
\hline $\begin{array}{l}2015 \\
\text { (1-летние) } \\
2016\end{array}$ & $0,009 \pm 0,001$ & $0,30 \pm 0,04$ & $0,5 \pm 0,1$ & $0,04 \pm 0,01$ & $0,3 \pm 0,1$ & $0,5 \pm 0,1$ & $0,05 \pm 0,01$ & $0,8 \pm 0,1$ & $4,5 \pm 0,7$ \\
\hline $\begin{array}{l}\text { (2-летние) } \\
2017\end{array}$ & $1,0 \pm 0,1$ & $6,30 \pm 2,00$ & $7,1 \pm 2,2$ & $0,40 \pm 0,10$ & $6,0 \pm 0,9$ & $6,3 \pm 0,7$ & $0,30 \pm 0,10$ & $12,6 \pm 1,5$ & $9,6 \pm 1,8$ \\
\hline $\begin{array}{l}\text { (3-летние) } \\
2018\end{array}$ & $2,7 \pm 0,7$ & $7,80 \pm 1,00$ & $8,1 \pm 0,8$ & $0,10 \pm 0,09$ & $7,4 \pm 1,2$ & $8,1 \pm 1,2$ & $0,30 \pm 0,07$ & $15,9 \pm 0,6$ & $13,7 \pm 0,8$ \\
\hline (4-летние) & $2,3 \pm 0,6$ & $5,60 \pm 1,30$ & $6,6 \pm 1,5$ & $0,05 \pm 0,02$ & $4,5 \pm 1,2$ & $7,4 \pm 1,5$ & $0,20 \pm 0,04$ & $12,1 \pm 1,2$ & $17,0 \pm 1,1$ \\
\hline
\end{tabular}

В год высадки (2015 год) мискантус сформировал хорошо развитый куст. Запас подземной биомассы (ПБ) в первый год вегетации превышал запас надземной (НБ) более чем в 5 раз. На второй год запас НБ превысил показатель первого года почти в 16 раз; запас ПБ увеличился примерно в 2 раза и достоверно не отличался от запаса НБ. На третий и четвертый годы вегетации величина НБ стабилизировалась, ПБ - продолжала возрастать. За 4 года урожайность НБ составила в среднем 10 т/га, ПБ - 11 т/га. 
В условиях нашего опыта в течение вегетационного периода в биомассе наиболее значимо изменялось содержание азота и калия (показатель снижался от всходов к высыханию в соответственно 9 и 6 раз) (табл. 3).

3. Содержание биофильных элементов в биомассе растений мискантуса (Miscanthus sacchariflorus) сорта Сорановский по фазам развития ( $n=12, M \pm \mathrm{SEM}$; Новосибирская обл., 5453'13,5"N, 8259'36,7"Е, 2015-2018 годы)

\begin{tabular}{l|c|c|c|c|c|c|c|c|c}
\hline \multirow{2}{*}{$\begin{array}{l}\text { Фаза } \\
\text { развития }\end{array}$} & \multicolumn{3}{|c|}{$\mathrm{N}$} & \multicolumn{3}{c|}{$\mathrm{P}$} & \multicolumn{3}{c}{$\mathrm{K}$} \\
\cline { 2 - 10 } Всходы & листья & стебель & метелка & листья & стебель & метелка & листья & стебель & метелка \\
Цветение & $1,08 \pm 0,20$ & $0,26 \pm 0,04$ & $1,37 \pm 0,25$ & $0,19 \pm 0,01$ & $0,11 \pm 0,02$ & $0,28 \pm 0,05$ & $1,38 \pm 0,11$ & $0,61 \pm 0,17$ & $1,21 \pm 0,25$ \\
Высыхание & $0,46 \pm 0,06$ & $0,24 \pm 0,09$ & $0,93 \pm 0,29$ & $0,12 \pm 0,04$ & $0,08 \pm 0,02$ & $0,14 \pm 0,05$ & $0,48 \pm 0,03$ & $0,26 \pm 0,02$ & $0,51 \pm 0,19$ \\
\hline
\end{tabular}

Одно из преимуществ мискантуса перед другими энергетическими растениями - низкий вынос биофильных элементов из почвы, поскольку при высыхании растений происходит интенсивный отток веществ из надземной биомассы в подземную (реутилизация). В год посадки (2015 год) биомассу не убирали с поля из-за ее небольшого количества (0,8 т/га), поэтому для сравнения были взяты последующие годы вегетации растения (2016-2018 годы). В нашем опыте конечная величина выноса элементов зависела от технологии уборки урожая (табл. 4). Если убирали только стебли, то вынос азота составлял 23,3; фосфора - 2,8; калия - 25,9 кг/га. Величина реутилизации составила соответственно 74, 69 и 76 \% от содержания элемента в фазу цветения. При уборке урожая с листьями отчуждение биофильных элементов повышалось примерно в 2 раза, а величина реутилизации снижалась соответственно до 43, 34 и $54 \%$.

4. Вынос и возврат (кг/га) в почву биофильных элементов по фазам развития растений мискантуса (Miscanthus sacchariflorus) сорта Сорановский $(n=12$, $M \pm$ SEM; Новосибирская обл., 5453'13,5”N, 8259'36,7"Е, 2016-2018 годы)

\begin{tabular}{|c|c|c|c|}
\hline Орган растения & $\mathrm{N}$ & $\mathrm{P}$ & $\mathrm{K}$ \\
\hline \multicolumn{4}{|c|}{ Цв е т е ни е } \\
\hline Листья & $65,1 \pm 7,3$ & $5,2 \pm 0,8$ & $67,4 \pm 8,9$ \\
\hline Стебель & $21,1 \pm 0,6$ & $3,6 \pm 0,2$ & $37,5 \pm 2,8$ \\
\hline Метелка & $2,4 \pm 0,6$ & $0,2 \pm 0,1$ & $1,8 \pm 0,6$ \\
\hline Сумма (вынос) & 88,7 & 8,9 & 106,7 \\
\hline \multicolumn{4}{|c|}{ В ыс ых ани е } \\
\hline Листья & $27,3 \pm 4,8$ & $3,1 \pm 0,3$ & $23,3 \pm 3,3$ \\
\hline Стебель & $22,1 \pm 1,8$ & $2,7 \pm 0,1$ & $25,5 \pm 1,5$ \\
\hline Метелка & $1,2 \pm 0,6$ & $0,1 \pm 0,1$ & $0,4 \pm 0,1$ \\
\hline Сумма (вынос общий) & 50,6 & 5,9 & 49,2 \\
\hline Вынос без листьев & 23,3 & 2,8 & 25,9 \\
\hline Возврат в почву с учетом листьев и стеблей & 38,1 & 3,0 & 57,5 \\
\hline Возврат в почву без учета листьев (сбор стеблей) & 65,4 & 6,1 & 80,8 \\
\hline
\end{tabular}

Для оценки баланса биофильных элементов в системе почва-растение оценили запас элементов в подземной биомассе как ближайшего источника питательных веществ. Запас N, P, K в ПБ составил соответственно 131, 10, 126 кг/га, то есть в 1,6-2,6 раз превышал количество, отчуждаемое с урожаем.

Таким образом, за 3 года вегетации мискантуса максимальный вынос N, Р и К с надземной биомассой растений составил соответственно 150 , 18 и 150 кг/га. Интересно было проследить, как это отразилось на агрохимических свойствах почвы. По общепринятой шкале (24) содержание фосфора и калия в исследуемой почве оценивается как высокое. После 4 лет вегетации мискантуса содержание фосфора, переходящего в вытяжку по Чирикову, как в верхнем, так и нижележащем горизонте почвы не изменилось (рис. 1, А). Содержание водорастворимых форм элемента (вытяжка Карпинского) в конце 2018 года в верхнем слое почвы было достоверно 
ниже в сравнении с исходным значением показателя, что отражает снижение запасов легкодоступного фосфора в почве при произрастании мискантуса (см. рис. 1, Б). При этом отметим, что содержание фосфора в почве оставалось на уровне градации «высокое». Обеспеченность почвы калием после 4 лет произрастания мискантуса не изменилась (см. рис. 1, В).
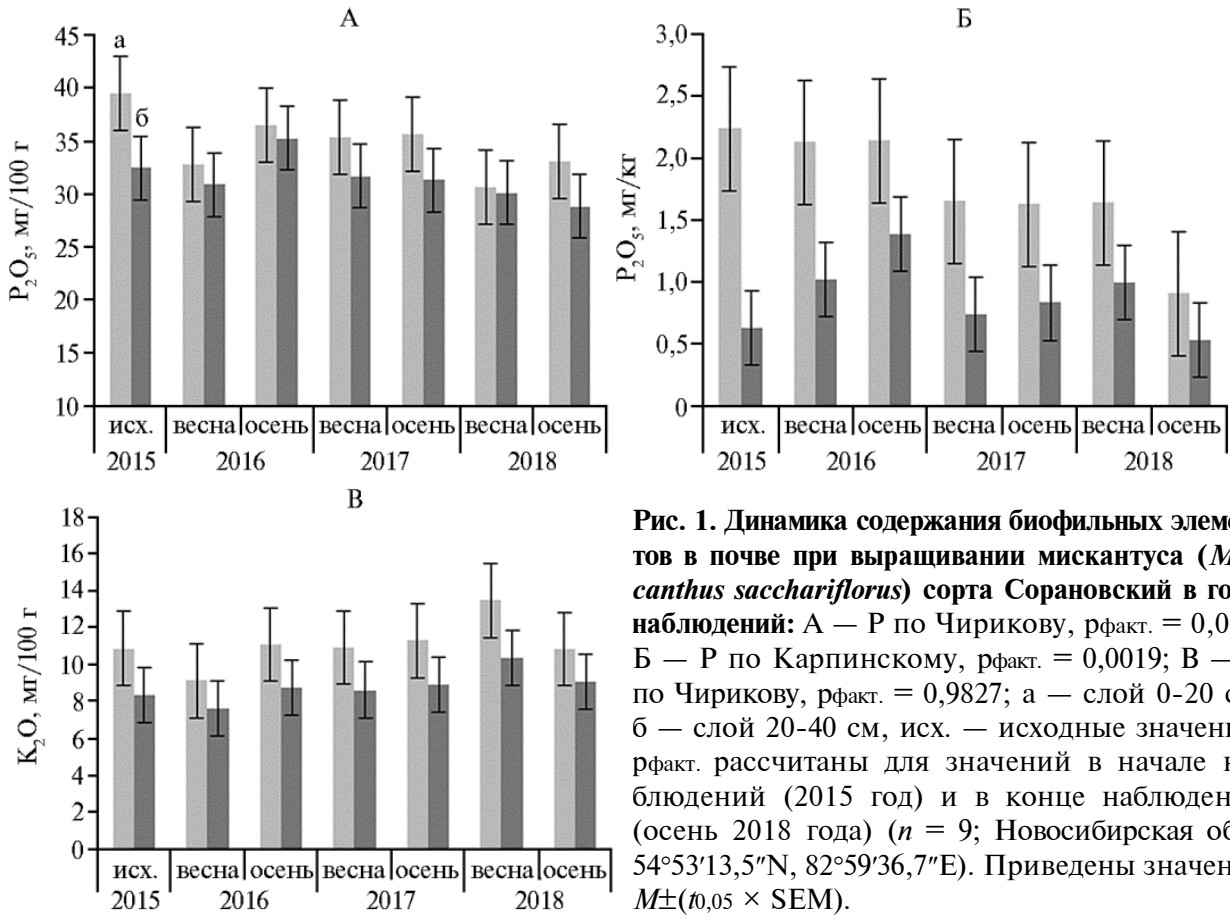

Рис. 1. Динамика содержания биофильных элементов в почве при выращивании мискантуса (Miscanthus sacchariflorus) сорта Сорановский в годы наблюдений: А - Р по Чирикову, рфакт. $=0,060$; Б - Р по Карпинскому, рфакт. $=0,0019 ; \mathrm{B}-\mathrm{K}$ по Чирикову, рфакт. $=0,9827$; а - слой 0-20 см, б - слой 20-40 см, исх. - исходные значения; рфакт. рассчитаны для значений в начале наблюдений (2015 год) и в конце наблюдений (осень 2018 года) ( $n=9$; Новосибирская обл., $\left.54^{\circ} 53^{\prime} 13,5^{\prime \prime} \mathrm{N}, 82^{\circ} 59^{\prime} 36,7^{\prime \prime} \mathrm{E}\right)$. Приведены значения $M \pm(t 0,05 \times \mathrm{SEM})$.

Получить подобные сведения по азоту в почве достаточно сложно из-за специфики круговорота этого элемента в агроценозе. Определение нитратного азота показало вполне ожидаемый результат: за период вегетации мискантуса в 2015-2017 годах в почве присутствовали лишь следовые количества этого соединения, в 2018 году нитратный азот мы не обнаружили. Низкое содержание нитратного азота характерно для многолетних посевов любых злаковых многолетних трав (20), поэтому незначительное содержание нитратного азота в нашем опыте не является свидетельством дефицита этого элемента для растений. Таким образом, за 4 года вегетации мискантуса в исследуемой агро-серой почве не обнаружено значительного снижения содержания основных биофильных элементов.

Интерес к данным по динамике углерода в посевах (посадках) энергетических культур связан с проблемой связывания парникового газа $\mathrm{CO}_{2}$ во фракциях ПОВ. После 4 лет вегетации мискантуса содержание Сорг. в слое почвы 0-20 см составило $1,97 \pm 0,16 \%$ ( $M \pm \mathrm{SEM})$, а в исходной почве $1,76 \pm 0,16 \%$, то есть достоверного накопления Сорг. в почве мы не установили. Как известно, содержание общего углерода в почве (Сорг.) - показатель весьма стабильный и отметить его изменение в краткосрочных опытах достаточно сложно (23). Тем не менее ориентировочные оценки возможны при помощи имеюшихся стандартных методов, в частности по динамике накопления углерода в подземной биомассе. В таблице 5 представлены данные по содержанию и запасам углерода и азота в мортмассе и корневищах мискантуса осенью 2016 года. В качестве исходных значений изучаемых показателей мы приняли их величины под однолетним паром, поскольку 
плантация мискантуса была заложена после однолетнего парования пшеничного поля. По содержанию углерода в подземной биомассе варианты опыта достоверно не различались (см. табл. 5). Уменьшение содержания азота в мортмассе при выращивании мискантуса в сравнении с исходной почвой свидетельствует о менее глубокой переработке органического материала в почве под мискантусом. Содержание азота в корневищах мискантуса было значительно ниже, чем в мортмассе, поэтому отношение $\mathrm{C} / \mathrm{N}$ резко возросло.

5. Содержание и запас азота и углерода в подземной биомассе и в почве под паром и под мискантусом (Miscanthus sacchariflorus) сорта Сорановский ( $n=10$, $M \pm \mathrm{SEM}$; Новосибирская обл., 5453'13,5”N , 8259'36,7"Е, осень 2016 года)

\begin{tabular}{|c|c|c|c|c|c|}
\hline \multirow{2}{*}{ Вариант } & \multicolumn{2}{|c|}{ Содержание, \% } & \multirow{2}{*}{$\mathrm{C} / \mathrm{N}$} & \multicolumn{2}{|c|}{ Запас, кг/га } \\
\hline & $\mathrm{N}$ & $\mathrm{C}$ & & $\mathrm{N}$ & $\mathrm{C}$ \\
\hline Пар (мортмасса) & $2,12 \pm 0,24$ & $43,39 \pm 1,01$ & $25 \pm 2,3$ & $40,3 \pm 3,9$ & $760 \pm 80$ \\
\hline Мискантус (мортмасса) & $0,79 \pm 0,04$ & $44,61 \pm 0,21$ & $66 \pm 3,3$ & $41 \pm 5,3$ & $2750 \pm 300$ \\
\hline Мискантус (корневища) & $0,48 \pm 0,05$ & $44,61 \pm 0,65$ & $96 \pm 13,3$ & $72 \pm 7,3$ & $4760 \pm 670$ \\
\hline
\end{tabular}

За два года произрастания мискантуса запас углерода в мортмассе вырос в сравнении с исходной величиной (пар) в 3,6 раза. В итоге общий запас углерода в ПБ мискантуса составил 7,5 т/га, то есть увеличился примерно в 10 раз в сравнении с показателем до закладки плантации. Повышение общего запаса углерода в ПБ происходило преимущественно за счет корневищ, где величина соотношения $\mathrm{C} / \mathrm{N}$ доходила до 100.

Таким образом, закрепление углерода в ПБ в первые 2 года вегетации мискантуса составило $1 \mathrm{~T} \mathrm{C} /$ га в год в мортмассе и 2 т С/га в год в корневищах. Эти данные дают общее представление о динамике ПОВ без учета изменений, происходящих в фракциях органического вещества самой почвы. Известен достаточно простой способ оценки количества самой доступной для микробного разложения мобильной фракции ПОВ. Почву инкубируют до тех пор, пока выделение С-CO 2 не перестанет возрастать (23). Однако понятно, что процедура эта достаточно длительная. В лабораторном опыте мы попытались оценить количество самой доступной части ПОВ, накопленной мискантусом за 2 первых года вегетации. Для этого почву изпод пара и из-под мискантуса инкубировали при оптимальных условиях тепла и влажности. Через 6 нед скорость продуцирования $\mathrm{CO}_{2}$ в образцах обеих почв достигла одинаковой величины (рис. 2).

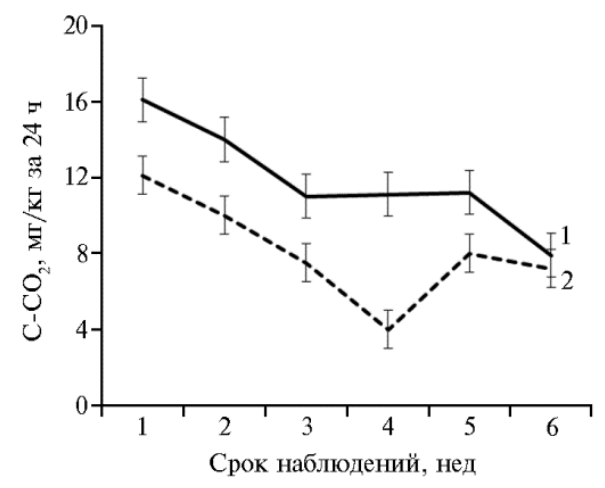

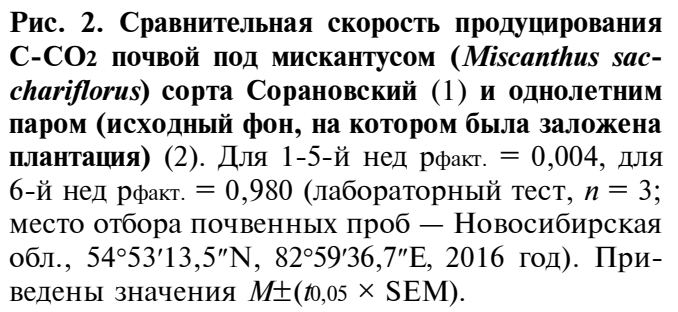

За 6 нед суммарное выделение углерода в виде $\mathrm{CO}_{2}$ из почвы под мискантусом составило 1039 25 кг/га, под

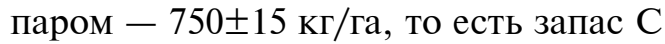
мобильной части органического вещества под мискантусом был почти на 300 кг/га больше, чем под паром. Из этого следует, что под посадками M. sacchariflorus сорта Сорановский за два вегетационных периода (20152016 годы) в почве накопилось около 300 кг С/га подвижного ПОВ в сравнении с его исходным запасом в почве однолетнего пара, на которой была заложена плантация. 
Содержание ПОВ обусловлено результирующей между скоростью поступления органических остатков в почву и их минерализации до конечных продуктов. Изменения составляющих баланса этих событий малы и, как следствие, интенсивность аккумуляции ПОВ сложно оценить. Но при помощи лабораторных измерений можно определить тенденции этого процесса, оценив дыхательный отклик почвы на внесение растительных остатков и таким образом измерить соотношение удаляемого и сохраняемого в почве ОВ. Отклик дыхательной активности почвы на поступление нового органического вещества служит одним из критериев интенсивности метаболизма углерода в почве: чем ниже отклик, тем ниже скорость минерализации, то есть динамика направлена в сторону накопления углерода в ПОВ.

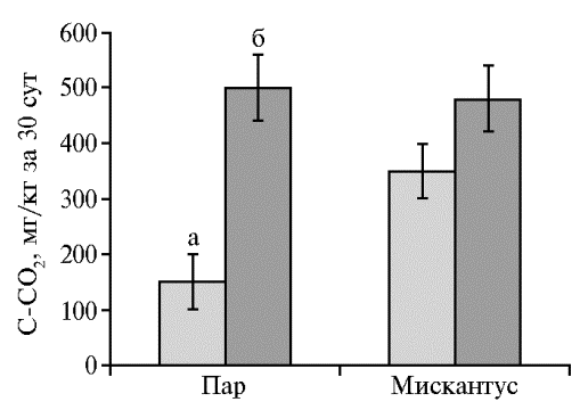

Рис. 3. Продукция С-СО2 почвой под однолетним паром (исходный фон, где была заложена плантация) и под мискантусом (Miscanthus sacchariflorus) сорта Сорановский в контроле (а) и при заделке соломы пшеницы (б). Для пара рфакт $<0,001$, для мискантуса рфакт. $=0,038$ (лабораторный тест, $n=3$; место отбора почвенных проб - Новосибирская обл., 5453'13,5"N , 82॰59'36,7"Е, 2016 год). Приведены значения $M \pm(t 0,05 \times \mathrm{SEM})$.

На рисунке 3 представлены результаты такого эксперимента. Из внесенного C (600 мг/кг в виде соломы) из почвы под паром выделилось примерно 350-400 мг С-CO2/кг, тогда как для почвы под мискантусом различия между вариантами (контроль и опыт) были минимальными. Дыхательный отклик для почвы пара составил 250 \%, для почвы под мискантусом - 40 \%. Из полученных данных следует, что микробное разложение поступившего нового органического вещества в почве при возделывании мискантуса было значительно слабее, чем на фоне пара. Торможение процессов минерализации в варианте с мискантусом, очевидно, связано с накоплением растительных остатков с высоким соотношением $\mathrm{C} / \mathrm{N}$.

6. Урожайность (абсолютно сухое вещество, т/га) разных видов мискантуса Miscanthus за 3 первых года вегетации, рассчитанная по данным литературы $(25,26)$

\begin{tabular}{l|l|c|c|c}
\hline Период уборки урожая & Значение & M. sinensis & M. sacchariflorus & M. giganteus \\
\hline Осень & Среднее & 12 & 15 & 26 \\
& Min-max & $4,6-22$ & $1,4-35,0$ & $13,8-37,8$ \\
Зима & Среднеe & 9 & 10 & 19 \\
& Min-max & $3,1-17,6$ & $0,4-22,4$ & $9,2-26,4$ \\
\hline
\end{tabular}

Таким образом, в представленной работе подведены итоги первого этапа изучения возможности выращивания мискантуса на биомассу в условиях Сибири. Наши данные получены в самых жестких климатических условиях (засушливый холодный климат) в сравнении с опубликованными в мире результатами. Тем не менее средняя урожайность M. sacchariflorus сорта Сорановский, установленная в нашей работе (10-13 т/га) (см. табл. 2), находится в пределах значений, характерных для этого вида (табл. 6). При анализе таблицы 6 обращает на себя внимание очень широкий размах колебаний урожайности мискантуса в мире. Это связано с тем, что авторы обзоров $(25,26)$ попытались собрать максимальный объем фактических данных, полученных в самых разных условиях - климатических, почвенных, агротехнических. При этом пределы колебаний урожайности у вида M. sacchariflorus были шире, чем у двух других видов. Это еще раз подтверждает 
вывод других авторов (11) о более выраженной зависимости урожайности M. sacchariflorus от почвенно-климатических условий.

7. Вынос биофильных элементов с биомассой мискантуса Miscanthus в разных регионах мира (по данным литературы)

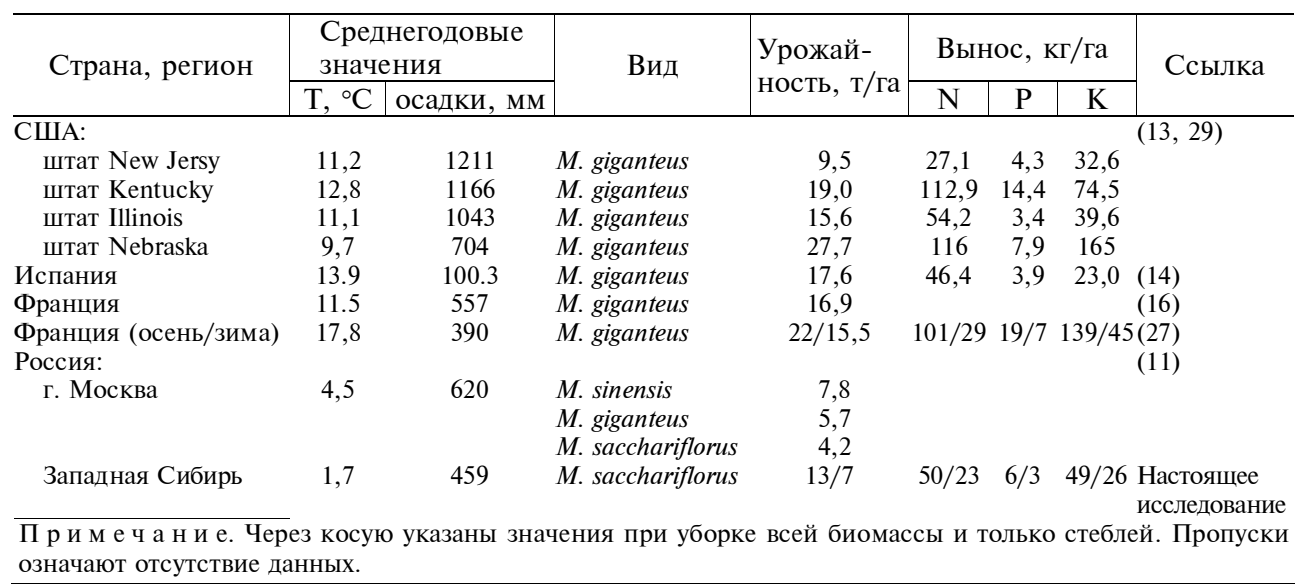

Сравнение полученных нами данных по выносу биофильных элементов провести достаточно сложно как географически, так и по видам мискантуса. Для России подобных сведений мы не обнаружили, кроме того, по странам мира эти сведения касаются преимущественно вида M. giganteus. Как видно из таблицы 7, с биомассой мискантуса наиболее интенсивно выносятся азот и калий. Общий вынос зависит от урожайности культуры и сроков уборки. Как показывают данные литературы $(27,28)$, при зимней уборке в сравнении с осенней вынос элементов может снизиться троекратно. Расчет выноса элементов на единицу урожая представлен в таблице 8. Показатель по разным источникам сильно колеблется. При этом в нашем опыте удельный вынос был достаточно низким и приближался к показателям (28), полученным в зимнюю уборку.

8. Вынос биофильных элементов с биомассой мискантуса Miscanthus (кг/т) в разных регионах мира при расчете на единицу массы урожая (расчеты на основе данных литературы, представленных в таблице 7)

\begin{tabular}{|c|c|c|c|c|}
\hline Страна, регион & Сроки/технология уборки & $\mathrm{N}$ & $\mathrm{P}$ & $\mathrm{K}$ \\
\hline США, штат New Jersy & Зима & 2,9 & 0,5 & 3,4 \\
\hline США, Штат Kentucky & Осень & 5,9 & 0,8 & 3,9 \\
\hline США, Штат Illinois & Осень & 3,5 & 0,2 & 2,5 \\
\hline США, Штат. Nebraska & Зима & 4,2 & 0,3 & 6,0 \\
\hline Испания & Зима & 2,6 & 0,2 & 1,3 \\
\hline \multirow[t]{2}{*}{ Франция } & Осень & 4,6 & 0,9 & 6,3 \\
\hline & Зима & 1,9 & 0,5 & 2,9 \\
\hline \multirow[t]{2}{*}{ Россия, Западная Сибирь (настоящее исследование) } & Уборка с листьями & 3,0 & 0,4 & 2,9 \\
\hline & Уборка стеблей & 1,4 & 0,2 & 1,5 \\
\hline
\end{tabular}

Таким образом, наши данные по урожайности и выносу элементов с биомассой в целом близки к показателям, полученным в мире в других почвенно-климатических условиях.

По динамике биофильных элементов в системе почва-растение, согласно данным литературы $(13,30)$, наиболее дефицитным элементом в многолетних посадках мискантуса является фосфор, который, несмотря на относительно низкий вынос, слабо реутилизируется. Такая же тенденция наблюдается в нашем опыте, хотя после 4 лет культивирования мискантуса мы отмечали снижение содержания только самой подвижной фракции этого элемента в почве. Анализ соотношения запасов элементов в подземной биомассе и их выноса показывает, что уже за первые годы вегетации сформировался 
достаточный запас азота, фосфора и калия для успешного возмещения выноса элементов с биомассой мискантуса. Ту же закономерность выявили исследования в других регионах мира. В частности, F.G. Dohleman с соавт. (12) в США (шт. Illinois, $40^{\circ} 03^{\prime} 21.3^{\prime \prime} \mathrm{N}, 88^{\circ} 12^{\prime} 3.4^{\prime \prime} \mathrm{W}$ ) показали, что за 5-7 лет вегетации урожайность M. giganteus (около 40 т/га) не снижалась даже без внесения удобрений. Авторы связывают это с динамичным высвобождением элементов, в частности азота, из корневищ и в целом из подземной биомассы. Так, запас азота в корневищах, составлявший в апреле 264 кг/га, к июню снижался до 145 кг/га, затем за счет реутилизации из надземной биомассы повышался к декабрю до 373 кг/га. Из представленных данных следует, что весной 45 \% азота, содержащегося в корневищах, активно поглощались отрастающей биомассой. В нашем опыте при выносе азота равном 50 кг/га (с учетом листьев) или 23 кг/га (при уборке только стеблей) запас элемента в корневищах составил 130 кг/га, то есть компенсация выноса была достаточной.

Таким образом, по результатам наших исследований, за 4 года развития растений $M$. sacchariflorus сорта Сорановский признаков истощения почвы биофильными элементами мы не выявили. Более того, за этот период сформировался значительный запас азота и углерода в подземной биомассе.

Возможность закрепления углерода парникового газа $\mathrm{CO}_{2}$ во фракциях ПОВ при произрастании мискантуса в целом не вызывает сомнений. В частности, для Великобритании разработан количественный прогноз, согласно которому при получении стабильных урожаев мискантуса 12 т/га в год, к 2090 году можно стабилизировать положительную динамику ПОВ (18). Подобные ожидания основаны преимущественно на колоссальной продуктивности надземной и подземной биомассы мискантуса. Величина закрепления углерода в ПБ в нашем опыте (примерно 1 т С/га в мортмассе, 2 т С/га в корневищах за год) достаточно близка к данным литературы. Так, по обобщенным данным A.D. Robertson с соавт. (17), под 3-4-летними посадками $M$. giganteus среднее за год накопление углерода в корнях составило около 860 кг С/га, в корневищах - 2660 кг С/га. Переход этого углерода в ПОВ - процесс динамичный, зависящий от скорости минерализации биомассы до конечных продуктов, которая обусловлена конкретными почвенно-климатическими и агротехническими условиями. Нами экспериментально показано, что на фоне мискантуса интенсивность этого процесса резко снизилась уже в первые 2 года вегетации из-за значительного повышения соотношения $\mathrm{C} / \mathrm{N}$, что может быть предпосылкой к накоплению органического вещества в почве. Как известно, дисбаланс между биофильными элементами служит наиболее эффективным природным механизмом, предотвращающим быстрое разложение биомассы на планете до конечных продуктов (31). В нашем опыте мы не обнаружили достоверного повышения содержания общего углерода в почве. Согласно публикациям, даже после 20 лет вегетации M. giganteus ожидаемого повышения содержания ПОВ может и не наблюдаться (17). Одна из вероятных причин - постепенная замена уже имеющегося ПОВ на вновь поступающее. Так, сообщалось (15), что за 6 лет в 10-летних посадках M. giganteus ежегодное пополнение ПОВ углеродом растений С4 составило 780 кг/га и $68 \%$ углерода детрита в слое почвы 0-10 см принадлежали мискантусу. При этом доля углерода мискантуса во фракции, устойчивой к окислению $\mathrm{NaOCl}$, составляла $15 \%$. Авторы подчеркивают, что пополнение устойчивых фракций ПОВ может происходить за относительно короткий период времени. Исследователи продолжают изучать причины, по которым накопление ПОВ под мискантусом часто не соответствует количеству поступающих растительных остатков. В частности, 
при помощи изотопа ${ }^{13} \mathrm{C}$ показано, что остатки растений $\mathrm{C} 4$ в почве минерализуются до конечных продуктов быстрее в сравнении с таковыми растений С3 (19). Таким образом, проблема закрепления углерода воздуха во фракциях ПОВ достаточна сложна и требует дополнительного изучения в конкретных почвенно-климатических условиях.

Итак, при плантационном выращивании Miscanthus sacchariflorus сорта Сорановский проведена оценка возможности его культивирования в условиях засушливого и холодного климата Западной Сибири. Установлено, что на агро-серой почве Центральной лесостепи Приобья в период формирования многолетних посадок (1-4 года) величина надземной биомассы мискантуса достигла 13 т/га, а средняя урожайность за 4 года составила 10 т/га. Эти показатели в целом сопоставимы с продуктивностью, наблюдаемой у $M$. sacchariflorus в мире при более благоприятных климатических условиях. Соотношение выноса основных биофильных элементов с урожаем надземной биомассы, а также достаточный запас последних в подземной биомассе позволяет сделать вывод об отсутствии истощения почвы элементами минерального питания растений при культивировании мискантуса. Этот вывод подтверждается устойчивостью агрохимических свойств исследуемой почвы за период наблюдений. Ориентировочные оценки компонентов баланса углерода (накопление C в мортмассе - 1 т/га, в мобильной фракции ПОВ - 150 кг/га в год) в агроэкосистеме показали наличие объективных предпосылок для закрепления углерода атмосферы во фракциях почвенного органического вещества. Таким образом, выращивание M. sacchariflorus на биомассу в условиях Сибири вполне обоснованно экологически, агротехнически и экономически.

Авторы благодарят заведующего лабораторией биотехнологии СибНИИРС филиал ИЦиГ СО РАН О.М. Поцелуева и старшего научного сотрудника лаборатории плодородия почв СибНИИЗиХ СФНЦА РАН С.А. Колбина за содействие в проведении полевых работ и анализе полученных материалов.

${ }^{1}$ Сибирский НИИ растениеводства и селекции филиал ФГБНУ Федеральный исследовательский центр Поступила в редакцию Институт цитологии и генетики

Сибирского отделения РАН, 630501 Россия, Новосибирская обл., р.п. Краснообск, ул. С-100, зд. 21, а/я 375 ,

e-mail: kapustyanchik@bionet.nsc.ru $\bowtie$, lihenko@mail.ru;

2ФГБУН Сибирский федеральный научный центр агробиотехнологий РАН, 633501 Россия, Новосибирская область, р.п. Краснообск, ул. Центральная,

e-mail: Danilova7alb@yandex.ru

Sel'skokhozyaistvennaya biologiya [Agricultural Biology], 2021, V. 56, № 1, pp. 121-134

\title{
Miscanthus sacchariflorus IN SIBERIA - BIOLOGICAL YIELD PARAMETERS AND DYNAMICS OF BIOFILIC ELEMENTS
}

\author{
S.Yu. Kapustyanchik ${ }^{\boxplus}$, A.A. Danilova ${ }^{2}$, I.E. Likhenko ${ }^{1}$
}

\footnotetext{
${ }^{1}$ Siberian Research Institute of Plant Cultivation and Breeding - Branch of Institute of Cytology and Genetics, SB $R A S$, 21, ul. C-100, Krasnoobsk, Novosibirsk Province, Russia 630501, e-mail kapustyanchik@bionet.nsc.ru ( $\square$ corresponding author), lihenko@mail.ru;

${ }^{2}$ Siberian Federal Scientific Center of Agro-Bio Technologies RAS, ul. Tsentralnaya, Krasnoobsk, Novosibirsk Province, 633501 Russia, e-mail Danilova7alb@yandex.ru ORCID:

Kapustyanchik S.Yu. orcid.org/0000-0002-2954-0620 Likhenko I.E. orcid.org/0000-0002-0305-1036

Danilova A.A. orcid.org/0000-0002-2212-3074

The authors declare no conflict of interests
} 
Acknowledgements:

The authors thank O.M. Potseluev, the Head of the Laboratory of Biotechnology SibNIIRS - Branch of the ICG SB RAS and S.A. Kolbin, the Senior Researcher of the Soil Fertility Laboratory, the Siberian Research Institute of Agriculture and Chemicalization of the Siberian Federal Scientific Center of Agro-Bio Technologies RAS for assistance in the field trials and analysis of biomaterials.

Supported financially by the budgetary project of the ICG SB RAS No. 0324-2019-0039-C-01 and the state assignment of the SFSCA RAS (project No. 0778-2018-0002)

Received June 26, 2020

doi: 10.15389/agrobiology.2021.1.121eng

Throughout the world, bioenergy crops are grown to replace fossil resources and reduce greenhouse gas emission. Miscanthus is one of the bioenergetic plants that is widely cultivated in countries with optimal hydrothermal conditions. There is little research on the specifics of Miscanthus spp. cultivation in the continental climate. The aim of the study was a preliminary assessment of the possibility of Miscanthus cultivation in Siberia. The production process of Miscanthus sacchariflorus cv. Soranovsky (The State Register of Breeding Achievements, patent No. 6931 dated 06/06/2013) was assessed under conditions of the Central Forest-Steppe of Novosibirsk Ob (Novosibirsk Province, $54^{\circ} 53^{\prime} 13,5^{\prime \prime} \mathrm{N}, 82^{\circ} 59^{\prime} 36,7^{\prime \prime}$ E, agro-gray soil, the experimental base of the Siberian Research Institute of Plant Cultivation and Breeding). During the formation of Miscanthus long-term stands (1-4 years), the aboveground biomass averaged $13 \mathrm{t} / \mathrm{ha}$, the belowground biomass $17 \mathrm{t} / \mathrm{ha}$. These figures are close to the average for this species in the world. The total $\mathrm{N}, \mathrm{P}$ and $\mathrm{K}$ removal with biomass of stems and leaves was 51,6 , and $49 \mathrm{~kg} / \mathrm{ha}$, and with stems it was only 23,3 , and $26 \mathrm{~kg} / \mathrm{ha}$, respectively. Accumulation of $\mathrm{N}, \mathrm{P}$ and $\mathrm{K}$ in the belowground biomass was 130,10 , and $126 \mathrm{~kg} / \mathrm{ha}$, respectively. Therefore, our experiment did not show any depletion of biophilic elements in soil during a four-year growth of miscanthus. Rough estimates have shown the presence of objective prerequisites for the atmospheric carbon sequestration in the fractions of the soil organic matter. During the first year of Miscanthus vegetation, at least $300 \mathrm{~kg} / \mathrm{ha}$ of carbon accumulated in the mobile fractions of the soil organic matter; an increase in the $\mathrm{C} / \mathrm{N}$ ratio in the belowground biomass of Miscanthus up to 74 vs. 20 in the initial soil was accompanied by a significant decrease in the mineralization rate of newly incoming plant residues. The parameters of the production process of Miscanthus sacchariflorus cv. Soranovsky on agro-gray soil in the Central Forest-Steppe of Novosibirsk Ob region correspond to the growth characteristics of $M$. sacchariflorus cultivated in other regions of the world on different soil types. We conclude that cultivation of $M$. sacchariflorus in Siberia is ecologically and commercially reasonable.

Keywords: bioenergy crops, Miscanthus sacchariflorus, cv. Soranovsky, aboveground biomass, belowground biomass, soil, nutrient removal, carbon sequestration.

\section{R E F E R E N C E S}

1. Lewandowski I., Clifton-Brown J., Trindade L.M., van der Linden G.C., Schwarz K.-U., MüllerSämann K., Anisimov A., Chen C.-L., Dolstra O., Donnison I.S., Farrar K., Fonteyne S., Harding G., Hastings A., Huxley L.M., Iqbal Y., Khokhlov N., Kiesel A., Lootens P., Meyer H., Mos M., Muylle H., Nunn C., Özgüven M., Roldán-Ruiz I., Schüle H., Tarakanov I., van der Weijde T., Wagner M., Xi Q., Kalinina O. Progress on optimizing Miscanthus biomass production for the European bioeconomy: results of the EU FP7 project OPTIMISC. Frontiers in Plant Science, 2016, 7(1620): 1-23 (doi: 10.3389/fpls.2016.01620).

2. Heaton E.A., Flavell R.B., Mascia P.N., Thomas S.R., Dohleman R.G., Long S.P. Herbaceous energy crop development: recent progress and future prospects. Current Opinion in Biotechnology, 2008, 19(3): 202-209 (doi: 10.1016/j.copbio.2008.05.001).

3. Anisimov A.A., Khokhlov N.F., Tarakanov I.G. Novye i netraditsionnye rasteniya i perspektivy ikh ispol'zovaniya, 2016, 12: 3-5 (in Russ.).

4. Otkrytyi onlain atlas-opredelitel' rastenii $i$ lishainikov Rossii $i$ sopredel'nykh stran. Available: http://www.plantarium.ru/page/view/item/41884.html [Open online atlas of plants and lichens in Russia and neighboring countries]. No date (in Russ.).

5. Clifton- Brown J.C., Lewandowski I. Overwintering problems of newly established Miscanthus plantations can be overcome by identifying genotypes with improved rhizome cold tolerance. New Phytologist, 2000, 148(2): 287-294 (doi.org/10.1046/j.1469-8137.2000.00764.x).

6. Pude R., Franken H. Reynoutria bohemica - eine Alternative zu Miscanthus $\times$ giganteus? Die Bodenkultur, 2001, 52(1): 19-27.

7. Dong H., Green S.V., Nishiwaki A., Yamada T., Stewart J.R., Deuter M., Sacks E.J. Winter hardiness of Miscanthus (I): Overwintering ability and yield of new Miscanthus $\times$ giganteus genotypes in Illinois and Arkansas. Global Change Biology - Bioenergy, 2018, 11(5): 691-705 (doi: 10.1111/gcbb.12588).

8. Shumnyi V.K., Veprev S.G., Nechiporenko N.N., Goryachkovskaya T.N., Slyn'ko N.M., Kolchanov N.A., Pel'tek S.E. Vavilovskii zhurnal genetiki i selektsii, 2010, 14(1): 122-126 (in Russ.).

9. Slyn'ko N.M., Goryachkovskaya T.N., Shekhovtsov S.V., Bannikova S.V., Burmakina N.V., 
Starostin K.V., Rozanov A.S., Nechiporenko N.N., Veprev S.G., Shumnyi V.K., Kolchanov N.A., Pel'tek S.E. Vavilovskii zhurnal genetiki i selektsii, 2013, 17(4-1): 765-771 (in Russ.).

10. Dorogina O.V., Vasil'eva O.Yu., Nuzhdina N.S., Buglova L.V., Gismatulina Yu.A., Zhmud' E.V., Zueva G.A., Komina O.V., Tsybchenko E.A. Vavilovskii zhurnal genetiki i selektsii, 2018, 22(5): 553559 (doi: 10.18699/VJ18.394) (in Russ.).

11. Nunn C., Hastings A.F.S.J., Kalinina O., Özgüven M., Schüle H., Tarakanov I.G., Van Der Weijde T., Anisimov A.A., Iqbal Y., Kiesel A., Khokhlov N.F., McCalmont J.P., Meyer H., Mos M., Schwarz K.U., Trindade L.M., Lewandowski I., Clifton-Brown J.C. Environmental influences on the growing season duration and ripening of diverse Miscanthus germplasm grown in six countries. Frontiers in Rlant Science, 2017, 8: 1-14 (doi: 10.3389/fpls.2017.00907).

12. Dohleman F.G., Heaton E.A., Arundale R.A., Long S.P. Seasonal dynamics of above- and below- ground biomass and nitrogen partitioning in Miscanthus $\times$ giganteus and Panicum virgatum across three growing seasons. Global Change Biology - Bioenergy, 2012, 4(5): 534-544 (doi: 10.1111/j.1757-1707. 2011.01153.x).

13. Masters M.D., Black C.K., Kantola I.B., Woli K.P., Voigt T., David M.V., DeLucia E.N. Soil nutrient removal by four potential bioenergy crops: Zea mays, Panicum virgatum, Miscanthus $\times$ giganteus, and prairie. Agriculture, Ecosystems and Environment, 2016, 216: 51-60 (doi: 10.1016/j.agee.2015.09.0160).

14. Oliveira J.A., West C.P., Afif E., Palencia P. Comparison of Miscanthus and Switchgrass cultivars for biomass yield, soil nutrients, and nutrient removal in Northwest Spain. Agronomy Journal, 2017, 109(1): 122-130 (doi: 10.2134/agronj2016.07.0440).

15. Poeplau C., Don A. Soil C changes under Miscanthus driven by C4 accumulation and C3 decompostion - toward a default sequestration function. Global Change Biology - Bioenergy, 2014, 6: 327-338 (doi: 10.1111/gcbb.12043).

16. Dufoss K. Effects of a 20-year old Miscanthus $\times$ giganteus stand and its removal on soil characteristics and greenhouse gas emissions. Biomass and Bioenergy, 2014, 69: 198-210 (doi: 10.1016/j.biombioe.2014.07.003).

17. Robertson A.D., Whitaker J., Morrison R., Davies C.A., Smith P., McNamara N.P. A Miscanthus plantation can be carbon neutral without increasing soil carbon stocks. Global Change Biology Bioenergy, 2017, 9(3): 645-661 (doi: 10.1111/gcbb.12397).

18. Shepherd A., Littleton E., Clifton- Brown J., Martin M., Hastings A. Projections of global and UK bioenergy potential from Miscanthus $\times$ giganteus - feedstock yield, carbon cycling and electricity generation in the 21st century. Global Change Biology - Bioenergy, 2020,12(4):287-305 (doi: $10.1111 / \mathrm{gcbb} .12671$ ).

19. Ye S., Hall S.J. Mechanisms underlying limited soil carbon gains in perennial and cover-cropped bioenergy systems revealed by stable isotopes. Global Change Biology - Bioenergy, 2020, 12(4): 101-117 (doi: 10.1111/gcbb.12657).

20. Peterburgskii A.V. Praktikum po agronomicheskoi khimii [Workshop on agrochemistry]. Moscow, 1968 (in Russ.).

21. Agrokhimicheskie metody issledovaniya pochv /Pod redaktsiei A.V. Sokolova [Agrochemical methods of soil srudy]. Moscow, 1975 (in Russ.).

22. Sharkov I.N. Pochvovedenie, 1984, 7: 136-143 (in Russ.).

23. Semenov V.M., Kogut B.M. Pochvennoe organicheskoe veshchestvo [Soil organic matter]. Moscow, 2015 (in Russ.).

24. Metodicheskie ukazaniya po provedeniyu kompleksnogo monitoringa plodorodiya zemel' sel'skokhozyaistvennogo naznacheniya [Guidelines for comprehensive monitoring of agricultural land fertility]. Moscow, 2003 (in Russ.).

25. Brosse N., Dufour A., Meng X., Sun Q., Ragauskas A. Miscanthus: a fast-growing crop for biofuels and chemicals production. Biofuels, Bioproducts and Biorefining, 2012, 6(5): 580-598 (doi: 10.1002/bbb.1353).

26. Lewandowski I., Clifton-Brown J.C., Andersson B., Basch G., Christian D.G., Jorgensen U., Jones M., Riche A., Schwarz K., Tayebi K., Teixeira F. Environment and harvest time affects the combustion qualities of Miscanthus genotypes. Agronomy Journal, 2003, 95: 1274-1280 (doi: 10.2134/agronj2003.1274).

27. Besnard A., Ferchaud F., Levrault F., Marsac S., Nguyen E., Savouré M.L. Lignoguide, savoir choisir une culture de biomasse. Bioénergie International, 2013, 26: 6-11.

28. Besnard A., Ferchaud F., Levrault F., Nguyen E., Marsac S., Savouré M.L. Le Lignoguide: une aide aux choix des cultures biomasse. Innovations Agronomiques, 2014, 34: 35-50.

29. Maughan M. Miscanthus $\times$ giganteus productivity: the effects of management in different environments. Global Change Biology - Bioenergy, 2012, 4: 253-265 (doi: 10.1111/j.1757-1707201101144.x).

30. Tubeilen F., Rennie T.J., Goss M.J. A review on biomass production from C4 grasses: yield and quality for end-use. Current Opinion in Plant Biology, 2016, 31: 172-180 (doi: 10.1016/j.pbi.2016.05.001).

31. Zavarzin G.A. Lektsii po prirodovedcheskoi mikrobiologii [Lectures on natural history of microbiology]. Moscow, 2004 (in Russ.). 